\title{
Lisianthus response to salinity stress
}

\author{
N. ASHRAFI and A. REZAEI NEJAD ${ }^{+}$ \\ Department of Horticultural Sciences, Faculty of Agriculture, Lorestan University, P.O. Box 465, Khorramabad, Iran
}

\begin{abstract}
The effect of salinity on some morpho-physiological characteristics in lisianthus cultivars was investigated. Cultivars namely, Blue Picotee $\left(C_{1}\right)$, Champagne $\left(C_{2}\right)$, Lime Green $\left(C_{3}\right)$, and Pure White $\left(C_{4}\right)$, were subjected to salt stress $(0-60 \mathrm{mM} \mathrm{NaCl})$ in a sand culture and their responses were measured. Our results showed that as a salinity level increased, growth parameters, relative water content, photosynthetic pigments, and gas-exchange characteristics decreased in all cultivars, while root fresh mass, root/shoot length ratio, electrolyte leakage, and a malondialdehyde content increased. However, the changes were less pronounced in $C_{3}$ and $C_{4}$ compared to $C_{1}$ and $C_{2}$. The regression analysis of the relationship between salinity levels and seedling height or root/shoot length ratio defined two groups with different slope coefficients: $C_{1}$ and $C_{2}$ as salt-sensitive cultivars and $C_{3}$ and $C_{4}$ as salt-tolerant cultivars. Shoot dry mass and leaf area tolerance indices were less affected by salinity in $C_{3}$ and $C_{4}$ compared to those in $C_{1}$ and $C_{2}$. Further, $C_{3}$ and $C_{4}$ showed higher photosynthetic rates, greater stomatal conductances, and accumulated greater $\mathrm{K}^{+}$and $\mathrm{Ca}^{2+}$ contents and $\mathrm{K}^{+} / \mathrm{Na}^{+}$ ratios in roots and shoots compared to those in $\mathrm{C}_{1}$ and $\mathrm{C}_{2}$. The results suggests that $\mathrm{C}_{3}$ and $\mathrm{C}_{4}$ could be recommended as resistant cultivars due to maintaining higher growth, water balance, leaf gas exchange, ion compartmentalization, and lower lipid peroxidation in response to salinity compared to $C_{1}$ and $C_{2}$.
\end{abstract}

Additional key words: cultivar; gas exchange; $\mathrm{NaCl}$-salinity; tolerance index.

\section{Introduction}

Currently, one third of all irrigated lands is affected by salinity worldwide and salinity stress remains one of the most serious environmental problems limiting crop production (Munns 2005, Turhan and Şeniz 2010). Irrigation with saline water introduces salt into the soil, resulting in a decrease of osmotic potential in root environment, thus making it difficult for roots to extract water from soils (Rengasamy 2006). Plant growth and productivity decline with increasing salinity due to interruption of certain morphological and physiological processes and certain types of ionic toxicity and nutritional imbalances (Morales et al. 1998, Valdez-Aguilar et al. 2014). Also, salinity reduces plant quality and marketability, and represents a significant challenge to ornamental horticultural production systems.

There are several strategies to cope with salinity problem in plant production, including improvements of irrigation methods, such as drip and subsurface irrigation system, reclamation of salinized lands, and other special horticultural techniques. However, these techniques are expensive, difficult to apply, and take a very long time to have an effect (Turhan and Şeniz 2010). While improvement of soil and water management can help to solve the problem, obtaining salt-tolerant cultivars is one of the most effective strategies to cope with salinity (Flowers and Yeo 1995, Essa 2002, Ruiz-Carrasco et al. 2011). Therefore screening salt tolerance in plants, particularly for landscaping projects and cut flowers production, is crucial for recommendations of suitable plants (Navarro et al. 2008). A number of studies have been conducted to investigate the degree of salt tolerance and the associated mechanisms in different crops, such as sunflower (Akram et al. 2009, Shahbaz et al. 2011), olive (Chartzoulakis et al. 2002), and ornamental shrubs (Cassaniti et al. 2009).

Lisianthus (Eustoma grandiflorum), native to the arid zones of the southern United States and northern Mexico, (Gómez-Pérez et al. 2014), is an ornamental plant of increasing demand. Lisianthus has become a consumer favorite in the cut flower market because of its exceptional

Received 28 February 2016, accepted 27 January 2017, published as online-first 13 March 2017.

${ }^{+}$Corresponding author, e-mail: Rezaeinejad.h@lu.ac.ir

Abbreviations: $\mathrm{C}_{1}-$ Blue Picotee; $\mathrm{C}_{2}-$ Champagne; $\mathrm{C}_{3}$ - Lime Green; $\mathrm{C}_{4}-$ Pure White; Chl - chlorophyll; DM - dry mass; $\mathrm{EL}$ - electrolyte leakage; $E$ - transpiration rate; FM - fresh mass; $g_{\mathrm{s}}$ - stomatal conductance; LA - leaf area; MDA - malondialdehyde; $P_{\mathrm{N}}-$ net photosynthetic rate; RWC - relative water content; TI - tolerance index. 
blooms and long vase life (Shimizu-Yumoto and Ichimura 2010). There are many lisianthus cultivars with morphological variations in flower color, size, and shape (Shimizu-Yumoto and Ichimura 2010). Tolerance to salt appears to be cultivar-dependent. Despite some interesting papers dealing with the environmental conditions required for lisianthus production, cultivar responses to $\mathrm{NaCl}$ salinity has not been extensively investigated. A recent report on lisianthus "Raf Shinn" showed salinity tolerance

\section{Materials and methods}

Experimental site: The experiment was conducted in a research greenhouse at the Faculty of Agriculture, Lorestan University, Iran $\left(32^{\circ} 37^{\prime} \mathrm{N}, 46^{\circ} 51^{\prime} \mathrm{E}\right)$ during 2015. Day and night air temperatures ranged between $22-32^{\circ} \mathrm{C}$ and $16-20^{\circ} \mathrm{C}$, respectively. Relative air humidity ranged between $55-65 \%$ and average daily PAR was $400-500$ $\mu \mathrm{mol}\left(\right.$ photon) $\mathrm{m}^{-2} \mathrm{~s}^{-1}$.

Experimental design and salinity treatments: The experiment was done with factorial arrangement based on a completely randomized design (CRD) with four replications. Seven salinity levels including: 0 (control), $10,20,30,40,50$, and $60 \mathrm{mM} \mathrm{NaCl}$ (corresponding to electrical conductivity (EC) of 1.7, 2.94, 4.14, 5.35, 6.25, 7.36 , and $8.45 \mathrm{dS} \mathrm{m}^{-1}$, respectively) were added to halfstrength Hoagland solution. The salinity levels were tested on four lisianthus cultivars $\left(\mathrm{C}_{1}, \mathrm{C}_{2}, \mathrm{C}_{3}\right.$, and $\left.\mathrm{C}_{4}\right) . \mathrm{F}_{1}$ hybrid seeds of the cultivars were obtained from Sakata Seed Company (Japan) and were sown in trays filled with cocopeat and perlite. Uniform seedlings were transferred into pots (one seedling per pot). Washed sand was used as the potting mixture and cultural practices were applied regularly. Seedlings were allowed to establish by fertigating them twice a day (at 09:00 and 14:00 h) with halfstrength Hoagland nutrient solution containing $2.5 \mathrm{mM} \mathrm{Ca}$ $\left(\mathrm{NO}_{3}\right)_{2}, 0.2 \mu \mathrm{M} \mathrm{CuSO}_{4}, 40 \mu \mathrm{M} \mathrm{Fe}$ (as Fe-EDTA), $23 \mu \mathrm{M}$ $\mathrm{H}_{3} \mathrm{BO}_{3}, 0.5 \mathrm{mM} \mathrm{KH}_{2} \mathrm{PO}_{4}, 2.5 \mathrm{mM} \mathrm{KNO}_{3}, 1.0 \mathrm{mM} \mathrm{MgSO}_{4}$, $4.5 \mu \mathrm{M} \mathrm{MnCl}_{2}, 0.2 \mu \mathrm{M} \mathrm{Na}_{2} \mathrm{MoO}_{4}$, and $0.4 \mu \mathrm{M} \mathrm{ZnSO}_{4}$. The $\mathrm{pH}$ of the nutrient solution was adjusted to $5.8 \pm 0.1$ and the EC was $1.7 \pm 0.1 \mathrm{dS} \mathrm{m}^{-1}$. One week after transplanting, salinity treatments were started with $10 \mathrm{mM} \mathrm{NaCl}$ and to avoid salt shock the concentration were increased by 10 $\mathrm{mM}$ per day to reach the desired salinity levels. Seedlings were fertilized with nutrient solution containing $\mathrm{NaCl}$ twice a day until flowering (approximately $70 \mathrm{~d}$ after transplanting).

Growth and tolerance indices (TIs): Growth characteristics were recorded in all seedlings from each experimental unit, including seedling height (from substrate surface to the top of the seedling), leaf area (LA), fresh mass (FM), and dry mass (DM) of both shoots and roots. The seedlings were harvested and separated into roots and shoots and their FM were measured. DM was recorded after oven-drying at $70^{\circ} \mathrm{C}$ for $72 \mathrm{~h}$. LA was meas- up to $8 \mathrm{dS} \mathrm{m}^{-1}$ (Valdez-Aguilar et al. 2013). However, salinity responses in other cultivars have not been tested. Therefore, the objective of the present study was to achieve a better understanding of the effect of irrigation with saline water on different lisianthus cultivars. The main focus of this study was the comparative study on $\mathrm{NaCl}$ salinity tolerance using growth parameters, photosynthetic attributes, and accumulation of ions in roots and shoots.

ured using a leaf area meter (Delta T-scan, Version 2.03; Delta-T Devices Ltd., Burwell, Cambridge, UK).

TI was calculated according to (Shi and Cai 2009) using the following equation:

$$
\mathrm{TI}=\left[100 \times\left(\mathrm{T}_{\mathrm{x}} / \mathrm{T}_{0}\right)\right]
$$

where $T_{x}$ is the value of the parameter as determined for stressed seedlings, and $\mathrm{T}_{0}$ is the value of the parameter as determined for control seedlings.

Ion concentrations: Dry tissues were ground to pass through a 40-mesh sieve, digested with 1.0 M hydrochloric acid, and then $\mathrm{Ca}^{2+}, \mathrm{Cl}^{-}, \mathrm{K}^{+}$, and $\mathrm{Na}^{+}$concentrations in roots and shoots were determined (Mills et al. 1996). $\mathrm{K}^{+}$ and $\mathrm{Na}^{+}$concentrations were determined by flame photometry (PFP7; Jenway, Chelmsford, Essex, UK). Chloride ion concentrations were determined by titration with $\mathrm{AgNO}_{3}$ in the presence of $\mathrm{K}_{2} \mathrm{CrO}_{4}$ (Anonymous 1915) and $\mathrm{Ca}^{2+}$ was determined using ethylenediaminetetraacetic acid (EDTA) (Walsh and Douglas 1972).

Gas-exchange parameters were measured on four fully expanded mature leaves, 60 and $70 \mathrm{~d}$ after treatments, using a portable infrared gas exchange analyser ( $L C A 4$, ADC Bioscientific, Ltd., Hoddesdon, England). Due to large number of seedlings for gas-exchange measurements, each replicate was measured for all treatments (all salinity levels and cultivars) randomly in one day from 9:30 to $11: 30 \mathrm{~h}$ and in total all measurement were completed in four successive days. The conditions of gasexchange measurement were: leaf surface area of $6.25 \mathrm{~cm}^{2}$, ambient $\mathrm{CO}_{2}$ concentration $\left(\mathrm{C}_{\mathrm{ref}}\right)$ of $350 \mu \mathrm{mol}$ $\mathrm{mol}^{-1}$, temperature of leaf chamber $\left(\mathrm{T}_{\mathrm{ch}}\right)$, relative humidity, and PAR at leaf surface varying from $26-29^{\circ} \mathrm{C}$, $58-62 \%$, and $420-460 \mu \mathrm{mol}$ (photon) $\mathrm{m}^{-2} \mathrm{~s}^{-1}$, respectively. Net photosynthetic rate $\left(P_{\mathrm{N}}\right)$, transpiration rate $(E)$, and stomatal conductance $\left(g_{\mathrm{s}}\right)$ measurements were carried out under steady-state conditions (about $60 \mathrm{~s}$ ).

Physiological and biochemical characteristics: Leaf chlorophyll (Chl $a$, Chl $b$, and Chl total) concentrations were determined according to Lichtenthaler (1987), using a spectrophotometer (U-1800 UV/VIS, Hitachi, Japan). Relative water content (RWC) was obtained from fully expanded leaves as $(\mathrm{FM}-\mathrm{DM}) /(\mathrm{FSM}-\mathrm{DM}) \times 100$, where 
FM is fresh mass, FSM is fresh saturated mass after rehydrating samples for 24-h in the dark, and DM is dry mass after oven-drying samples at $70^{\circ} \mathrm{C}$ to constant mass. Electrolyte leakage (EL) was measured following the method of Lutts et al. (1996) to assess membrane permeability using an electrical conductivity meter. Lipid peroxidation was estimated by measuring the formation of malondialdehyde (MDA) according to Wang et al. (2009).

\section{Results}

Seedling height: The results showed that as salinity level increased, seedling height of all tested cultivars decreased (Fig. 1A). However, the decline in seedling height of $\mathrm{C}_{1}$ and $\mathrm{C}_{2}$ started at $20 \mathrm{mM} \mathrm{NaCl}$, while, seedling height of $\mathrm{C}_{3}$ and $\mathrm{C}_{4}$ was reduced at 50 and $40 \mathrm{mM} \mathrm{NaCl}$, respectively. The regression analysis of the relationship between salinity levels and seedling height ( $\%$ of control values) showed two groups with different slope coefficients: $\mathrm{C}_{1}$ and $\mathrm{C}_{2}$ with an average slope of -0.87 , and $\mathrm{C}_{3}$ and $\mathrm{C}_{4}$ with an average slope of -0.49 . Within a group, slope coefficients of cultivars were not different significantly, while, there was a significant difference $(P<0.05)$ between the two groups (Fig. 1B).

Root and shoot FM: As salinity level increased, shoot FM decreased in all cultivars (Fig. 2). In contrast, the response of root FM to salinity was different in each cultivar. In $\mathrm{C}_{2}$, $\mathrm{C}_{3}$ and $\mathrm{C}_{4}$ root $\mathrm{FM}$ increased with increasing salinity, while, root $\mathrm{FM}$ of $\mathrm{C}_{1}$ did not show any clear change in response to salinity.

The root/shoot length ratio increased with increasing $\mathrm{NaCl}$ concentration (Fig. 3). Similarly to the seedling height, the root/shoot length ratio $v s$. salinity also defined two groups with different slope coefficients: $C_{1}$ and $C_{2}$ cultivars with an average slope of 0.023 , and $\mathrm{C}_{3}$ and $\mathrm{C}_{4}$ with an average slope of 0.0093 . Within a group, slope coefficients of cultivars were not different significantly, while, there was a significant difference $(P<0.05)$ between the two groups.

TI: Shoot DM and LA TIs of $\mathrm{C}_{1}$ and $\mathrm{C}_{2}$ were more affected by salinity than those of $\mathrm{C}_{3}$ and $\mathrm{C}_{4}$ (Fig. 4). In addition, root $\mathrm{K}^{+} / \mathrm{Na}^{+}$TI was higher in $\mathrm{C}_{3}$ than that of the other cultivars. Shoot $\mathrm{K}^{+} / \mathrm{Na}^{+}$TI was lower in $\mathrm{C}_{1}$ and $\mathrm{C}_{2}$ than that in $\mathrm{C}_{3}$ and $\mathrm{C}_{4}$.

Element concentrations: As the salinity level increased, the concentration of $\mathrm{Cl}^{-}$and $\mathrm{Na}^{+}$increased, while, $\mathrm{Ca}^{2+}$ and $\mathrm{K}^{+}$contents and $\mathrm{K}^{+} / \mathrm{Na}^{+}$ratio decreased (Table 1 ). $\mathrm{C}_{3}$ and $\mathrm{C}_{4}$ accumulated greater $\mathrm{K}^{+}$and $\mathrm{Ca}^{2+}$ contents in roots and shoots than those of $\mathrm{C}_{1}$ and $\mathrm{C}_{2}$. Further, shoot $\mathrm{K}^{+} / \mathrm{Na}^{+}$ratios in $\mathrm{C}_{3}$ and $\mathrm{C}_{4}$ were higher than those of $\mathrm{C}_{1}$ and $\mathrm{C}_{2}$. A strong positive correlation was found between shoot $\mathrm{K}^{+}$content and shoot FM $(r=0.61, P<0.0001)$. In addition, there were
Data analysis: The data were subjected to analysis of variance using SAS statistical software (Version 9.1; SAS Institute, Cary, $\mathrm{NC}$, USA). Mean comparisons were done according to the least significant difference (LSD) at $P \leq 0.05$. The slopes of linear regressions between the $\mathrm{NaCl}$ concentrations and seedlings height of lisianthus cultivars were calculated and tested using GraphPad Prism 5 to verify if slopes of the two regression lines were statistically different $(P \leq 0.05)$

significant negative correlations between both root and shoot $\mathrm{Na}^{+}$with shoot $\mathrm{K}^{+}$contents $(r=-0.39, P=0.0002$ and $r=-0.46, P<0.0001$ for roots and shoots, respectively).

Gas-exchange characteristics: $P_{\mathrm{N}}, E$, and $g_{\mathrm{s}}$ decreased with increasing $\mathrm{NaCl}$ concentration (Table 2). For example, $P_{\mathrm{N}}$ of seedlings grown under $60 \mathrm{mM} \mathrm{NaCl}$ on 60 and $70 \mathrm{~d}$ after treatment decreased by 51 and $41 \%$, respectively, compared with control. Moreover, $\mathrm{C}_{4}$ showed the highest $P_{\mathrm{N}}$, followed by $\mathrm{C}_{1}$ and $\mathrm{C}_{3}$, and the lowest $P_{\mathrm{N}}$ was found in $\mathrm{C}_{2} . \mathrm{C}_{4}$ showed higher $E$ than in the other cultivars, while, the highest $g_{\mathrm{s}}$ was found in $\mathrm{C}_{3}$.

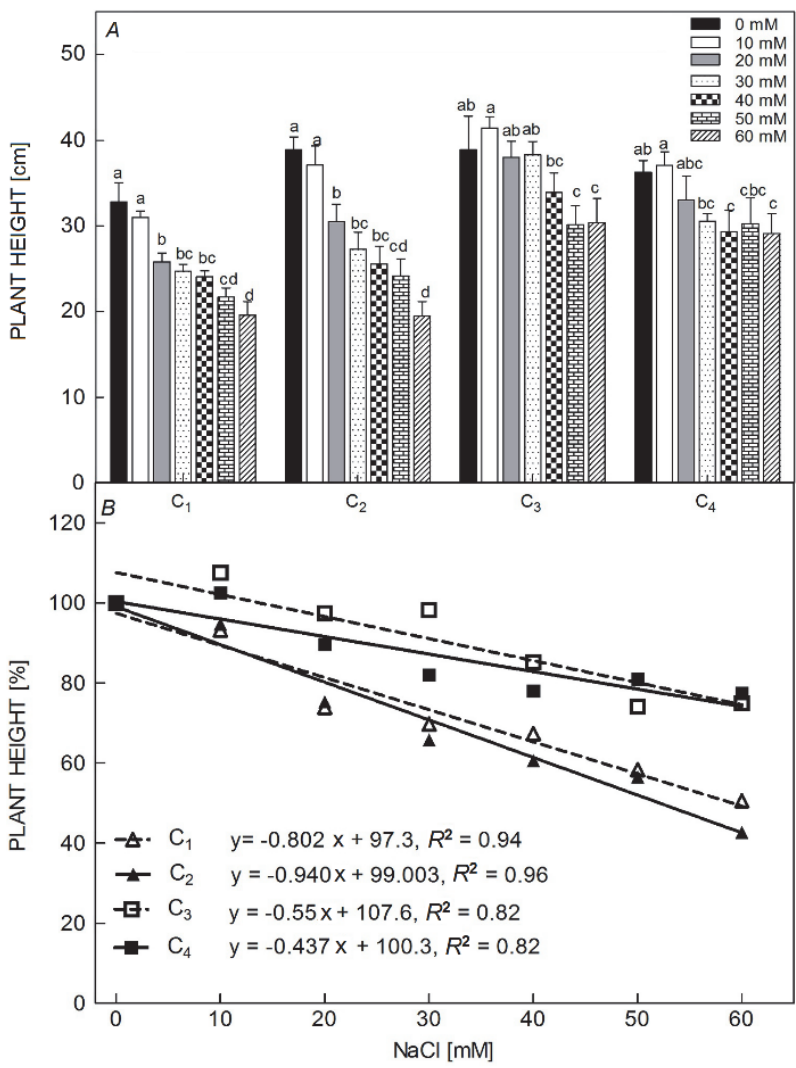

Fig. 1. The effect of salinity levels on seedling height $(A$ : absolute values, $B$ : linear regression) of four lisianthus cultivars. $\mathrm{C}_{1}-$ Blue Picotee, $\mathrm{C}_{2}$ - Champagne, $\mathrm{C}_{3}$ - Lime Green, $\mathrm{C}_{4}-$ Pure White. $P_{\text {cultivar }}<0.0001, P_{\text {salinityr }}<0.0001, P_{\text {cultivar } \times \text { salinity }}=0.258$. 

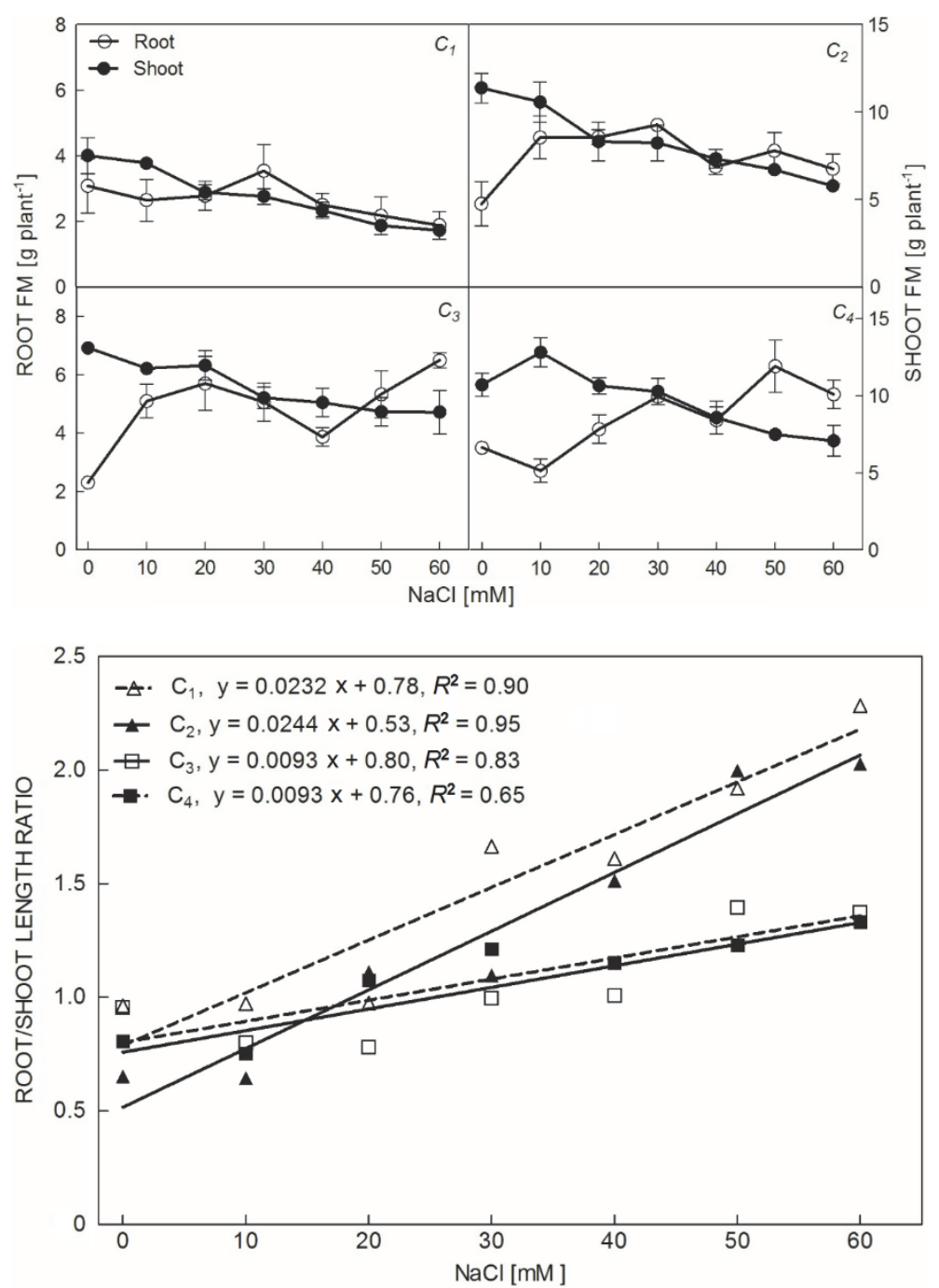

Fig. 2. Changes of root and shoot fresh mass (FM) of lisianthus cultivars at different salinity concentrations. $\mathrm{C}_{1}-$ Blue Picotee, $\mathrm{C}_{2}-$ Champagne, $\mathrm{C}_{3}$ - Lime Green, $\mathrm{C}_{4}-$ Pure White. Root FM: $P_{\text {cultivar }}<0.0001, P_{\text {salinity }}=0.029, P_{\text {cultivar } \times \text { salinity }}=0.185$; shoot FM: $\quad P_{\text {cultivar }}<0.0001, \quad P_{\text {salinity }}<0.0001$, $P_{\text {cultivar } \times \text { salinity }}=0.686$.

Fig. 3. The effect of salinity levels on root/shoot length ratio of four lisianthus cultivars. $\mathrm{C}_{1}-$ Blue Picotee, $\mathrm{C}_{2}-$ Champagne, $\mathrm{C}_{3}-$ Lime Green, $\mathrm{C}_{4}-$ Pure White.

Membrane lipid peroxidation: Salinity impaired membrane permeability as shown by larger EL and MDA content in seedlings grown under higher salinity levels compared with controls (Table 3 ). However, $\mathrm{C}_{1}$ and $\mathrm{C}_{2}$ were more sensitive than $\mathrm{C}_{3}$ and $\mathrm{C}_{4}$.

Leaf Chl content decreased with the increasing $\mathrm{NaCl}$

\section{Discussion}

The general pattern of plant responses to salinity shows a growth suppression depending on salt concentrations and plant species, and these responses have been used in many studies as a measure of resistance to saline conditions (Chartzoulakis et al. 2002, Cassaniti et al. 2009, Shahbaz et al. 2011). According to our results, $\mathrm{NaCl}$ treatments reduced seedling growth due to decreased $P_{\mathrm{N}}, g_{\mathrm{s}}$, and RWC and increased EL and MDA content. Similar results have been reported previously (Sairam et al. 2002, Hafsi et al. 2007, Maggio et al. 2007, Pérez-Tornero et al. 2009, Tarchoune et al. 2012). In current research, the growth parameters of all cultivars were reduced by salinity, concentration. $\mathrm{C}_{3}$ and $\mathrm{C}_{4}$ showed higher $\mathrm{Chl}$ contents compared to $\mathrm{C}_{1}$ and $\mathrm{C}_{2}$ (Table 3 ).

RWC: Lower RWCs were found in seedlings treated with higher $\mathrm{NaCl}$ concentrations. Moreover, $\mathrm{C}_{4}$ showed the highest RWC, followed by $\mathrm{C}_{1}$ and $\mathrm{C}_{3}$, and the lowest RWC was found in $\mathrm{C}_{2}$ (Table 3).

though, the decrease in the $\mathrm{C}_{1}$ and $\mathrm{C}_{2}$ appeared to be greater than that in $\mathrm{C}_{3}$ and $\mathrm{C}_{4}$. It has been reported that lisianthus 'Raf Shinn' could be grown profitably when irrigated with saline water with an EC of $8 \mathrm{dS} \mathrm{m}^{-1}$, without measurable effects (Valdez-Aguilar et al. 2013). However, sensitive and resistant cultivars in the present study responded to salinity at 20 and $50 \mathrm{mM} \mathrm{NaCl}$ (equal to 4.14 and $7.36 \mathrm{dS} \mathrm{m}^{-1}$ ), respectively. The differences could be related to different responses of cultivars to salinity.

In the present research, root FM in three out of four tested cultivars increased as salinity increased (Fig. 2). Increased root biomass in response to salinity have been 


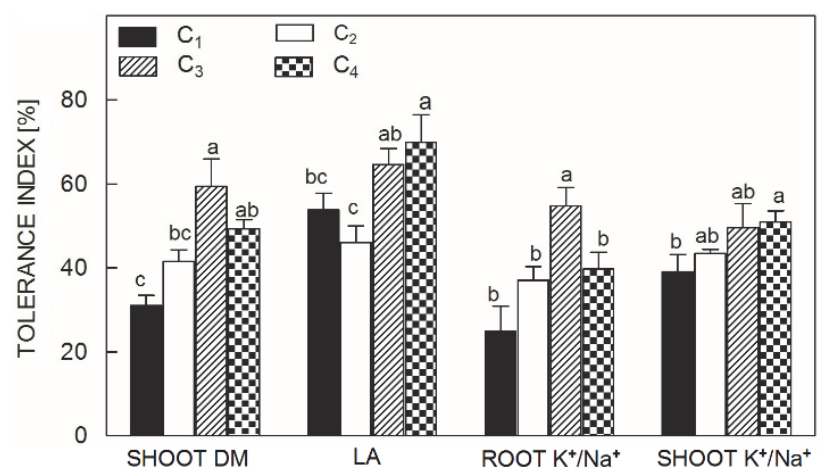

Fig. 4. Tolerance indices (TI) of shoot dry mass (DM), leaf area (LA), root and shoot $\mathrm{K}+/ \mathrm{Na}+$ ratio in control and $60 \mathrm{mM} \mathrm{NaCl}-$ treated seedlings of four lisianthus cultivars. $\mathrm{C}_{1}-$ Blue Picotee, $\mathrm{C}_{2}$ - Champagne, $\mathrm{C}_{3}$ - Lime Green, $\mathrm{C}_{4}-$ Pure White. Shoot DM: $P=0.0018$; LA: $P=0.015$; $\operatorname{root} \mathrm{K}^{+} / \mathrm{Na}^{+}: P=0.0062$; shoot $\mathrm{K}^{+} / \mathrm{Na}^{+}$: $P=0.0018$. reported previously (Maggio et al. 2007, Pattanagul and Thitisaksakul 2008). This has been attributed to the reallocation of photosynthates into roots more than shoots (Saab et al. 1990, Pattanagul and Thitisaksakul 2008). Further, our results revealed that root/shoot length ratio increased with increasing salinity, however, sensitive cultivars $\left(C_{1}\right.$ and $\left.C_{2}\right)$ showed larger root/shoot length ratio compared to tolerant cultivars $\left(\mathrm{C}_{3}\right.$ and $\left.\mathrm{C}_{4}\right)$ (Fig. 3). This could be due to higher decline of shoot length in sensitive cultivars in response to salinity compared to that in tolerant cultivars (Fig. 1).

The analysis of TI was used as a simple and effective method to select salt-tolerant cultivars at different salt concentrations. Cultivars with higher TI, showing lesser decreases in seedlings height and biomass could be more tolerant than those with lower TI (Turhan and Şeniz 2010, Sharma et al. 2013). The results of current study showed

Table 1. Effect of $\mathrm{NaCl}$ salinity on the concentration of some nutrient elements $\left[\mathrm{mg} \mathrm{g}^{-1}\right.$ ] in the shoots and roots of four lisianthus cultivars. $\mathrm{C}_{1}-$ Blue Picotee; $\mathrm{C}_{2}-$ Champagne; $\mathrm{C}_{3}$ - Lime Green; $\mathrm{C}_{4}$ - Pure White. Mean values in each column followed by the same lowercase letters did not differ significantly at $P \leq 0.05$ according to LSD.

\begin{tabular}{|c|c|c|c|c|c|c|c|c|c|c|}
\hline Treatment & $\begin{array}{l}\mathrm{Cl}^{-} \\
\text {Root }\end{array}$ & $\mathrm{Ca}^{2+}$ & $\mathrm{Na}^{+}$ & $\mathrm{K}^{+}$ & $\mathrm{K}^{+} / \mathrm{Na}^{+}$ & $\begin{array}{l}\mathrm{Cl}^{-} \\
\text {Shoot }\end{array}$ & $\mathrm{Ca}^{2+}$ & $\mathrm{Na}^{+}$ & $\mathrm{K}^{+}$ & $\mathrm{K}^{+} / \mathrm{Na}^{+}$ \\
\hline \multicolumn{11}{|l|}{ Cultivar } \\
\hline $\mathrm{C}_{1}$ & $3.84^{\mathrm{a}}$ & $0.44^{\mathrm{b}}$ & $9.2^{\mathrm{a}}$ & $5.5^{\mathrm{c}}$ & $0.69^{\mathrm{a}}$ & $2.26^{\mathrm{a}}$ & $0.21^{\mathrm{c}}$ & $12.7^{\mathrm{a}}$ & $7.8^{\mathrm{b}}$ & $0.65^{\mathrm{b}}$ \\
\hline $\mathrm{C}_{2}$ & $4.03^{\mathrm{a}}$ & $0.45^{\mathrm{b}}$ & $9.9^{\mathrm{a}}$ & $5.4^{\mathrm{c}}$ & $0.58^{\mathrm{b}}$ & $2.14^{\mathrm{a}}$ & $0.25^{\mathrm{b}}$ & $12.3^{\mathrm{ab}}$ & $8.2^{\mathrm{b}}$ & $0.71^{b}$ \\
\hline $\mathrm{C}_{3}$ & $3.82^{\mathrm{a}}$ & $0.52^{\mathrm{a}}$ & $10.08^{\mathrm{a}}$ & $6.8^{\mathrm{a}}$ & $0.70^{\mathrm{a}}$ & $2.23^{\mathrm{a}}$ & $0.30^{\mathrm{a}}$ & $11.9^{\mathrm{ab}}$ & $9.7^{\mathrm{a}}$ & $0.86^{\mathrm{a}}$ \\
\hline $\mathrm{C}_{4}$ & $4.01^{\mathrm{a}}$ & $0.51^{\mathrm{ab}}$ & $10.1^{\mathrm{a}}$ & $6.05^{\mathrm{b}}$ & $0.64^{\mathrm{ab}}$ & $2.23^{\mathrm{a}}$ & $0.31^{\mathrm{a}}$ & $11.4^{b}$ & $10.01^{\mathrm{a}}$ & $0.9^{\mathrm{a}}$ \\
\hline LSD & 0.45 & 0.07 & 0.98 & 0.55 & 0.103 & 0.48 & 0.04 & 0.57 & 0.98 & 0.102 \\
\hline \multicolumn{11}{|l|}{$\mathrm{NaCl}[\mathrm{mM}]$} \\
\hline 0 & $2.9^{\mathrm{c}}$ & $0.72^{\mathrm{a}}$ & $6.5^{\mathrm{e}}$ & $6.9^{\mathrm{a}}$ & $1.11^{\mathrm{a}}$ & $1.56^{\mathrm{d}}$ & $0.26^{\mathrm{b}}$ & $9.4^{\mathrm{d}}$ & $10.1^{\mathrm{a}}$ & $1.10^{\mathrm{a}}$ \\
\hline 10 & $3.54^{\mathrm{b}}$ & $0.73^{\mathrm{a}}$ & $8.7^{\mathrm{d}}$ & $6.4^{\mathrm{abc}}$ & $0.73^{b}$ & $1.74^{\mathrm{cd}}$ & $0.33^{\mathrm{a}}$ & $9.9^{d}$ & $9.6^{\mathrm{ab}}$ & $0.98^{\mathrm{a}}$ \\
\hline 20 & $3.44^{\mathrm{bc}}$ & $0.42^{\mathrm{bc}}$ & $9.58^{\mathrm{cd}}$ & $6.6^{\mathrm{ab}}$ & $0.7^{\mathrm{bc}}$ & $2.08^{\mathrm{cd}}$ & $0.37^{\mathrm{a}}$ & $12.03^{c}$ & $9.6^{\mathrm{abc}}$ & $0.81^{\mathrm{b}}$ \\
\hline 30 & $3.74^{\mathrm{b}}$ & $0.46^{\mathrm{b}}$ & $10.1^{\mathrm{bc}}$ & $5.8^{\mathrm{cd}}$ & $0.58^{\mathrm{cd}}$ & $1.89^{\mathrm{cd}}$ & $0.26^{\mathrm{b}}$ & $12.8^{\mathrm{bc}}$ & $8.9^{\mathrm{bc}}$ & $0.71^{b c}$ \\
\hline 40 & $3.9^{\mathrm{b}}$ & $0.41^{b c}$ & $10.9^{\mathrm{ab}}$ & $5.9^{\mathrm{bc}}$ & $0.55^{\mathrm{de}}$ & $2.36^{\mathrm{bc}}$ & $0.187^{\mathrm{c}}$ & $13.3^{\mathrm{ab}}$ & $8.8^{\mathrm{cd}}$ & $0.67^{\mathrm{c}}$ \\
\hline 50 & $5.0^{\mathrm{a}}$ & $0.35^{\mathrm{cd}}$ & $11.04^{\mathrm{ab}}$ & $5.09^{\mathrm{de}}$ & $0.47^{\mathrm{de}}$ & $3.01^{\mathrm{a}}$ & $0.24^{\mathrm{b}}$ & $13.2^{\mathrm{abc}}$ & $8.1^{\mathrm{de}}$ & $0.67^{\mathrm{c}}$ \\
\hline 60 & $4.8^{\mathrm{a}}$ & $0.29^{\mathrm{d}}$ & $11.9^{\mathrm{a}}$ & $4.94^{\mathrm{e}}$ & $0.42^{\mathrm{e}}$ & $2.87^{\mathrm{ab}}$ & $0.244^{\mathrm{bc}}$ & $14.1^{\mathrm{a}}$ & $7.4^{\mathrm{e}}$ & $0.53^{d}$ \\
\hline LSD & 0.6 & 0.092 & 1.3 & 0.73 & 0.136 & 0.63 & 0.76 & 0.05 & 1.29 & 0.135 \\
\hline$P_{\text {cultivar }}$ & 0.703 & 0.056 & 0.272 & $<0.0001$ & 0.071 & 0.966 & 0.0001 & 0.052 & $<0.0001$ & $<0.0001$ \\
\hline$P_{\text {salinity }}$ & $<0.0001$ & $<0.0001$ & $<0.0001$ & $<0.0001$ & $<0.0001$ & $<0.0001$ & $<0.0001$ & $<0.0001$ & $<0.0001$ & $<0.0001$ \\
\hline$P_{\text {cultivar } \times \text { salinity }}$ & 0.317 & 0.45 & 0.241 & 0.782 & 0.081 & 0.989 & 0.256 & 0.057 & 0.532 & 0.128 \\
\hline
\end{tabular}

that $\mathrm{C}_{3}$ and $\mathrm{C}_{4}$ were more tolerant than $\mathrm{C}_{1}$ and $\mathrm{C}_{2}$, as they showed higher growth (Figs. 1, 2, 3) and TIs (Fig. 4).

Reduced growth under saline conditions could be partly due to high concentrations of salt accumulated in the growing tissues and low absorption of nutrient ions, i.e., $\mathrm{Ca}^{2+}$ or $\mathrm{K}^{+}$(Sharma et al. 2013). All cultivars tested here, tended to decrease $\mathrm{K}^{+}$and $\mathrm{Ca}^{2+}$ contents and to increase $\mathrm{Na}^{+}$and $\mathrm{Cl}^{-}$contents in response to increasing salinity level (Table 1). This could be due to the antagonistic effect of $\mathrm{Na}^{+}$on $\mathrm{K}^{+}$and $\mathrm{Ca}^{2+}$ absorption caused by a decreased water potential in the root environment, as reported previously (Mavrogianopoulos et al. 2002, Sairam et al. 2002, Turhan and Şeniz 2010). Lower accumulation of toxic ions (i.e., $\mathrm{Na}^{+}$and $\mathrm{Cl}^{-}$), and higher capacity for $\mathrm{Ca}^{2+}$ or $\mathrm{K}^{+}$uptake in seedlings tissues resulting in higher $\mathrm{K}^{+} / \mathrm{Na}^{+}$ ratio, are characteristics of tolerant cultivars (Poustini and Siosemardeh 2004, Izadi et al. 2014). $C_{3}$ and $C_{4}$ in the present research were able to maintain a constant $\mathrm{K}^{+}$ content independently of $\mathrm{Na}^{+}$and $\mathrm{Cl}^{-}$accumulation (Table 1), suggesting an efficient salt compartmentalization. Further, $\mathrm{K}^{+} / \mathrm{Na}^{+}$ratio in tolerant cultivars was higher than that of the sensitive ones. Similar findings have been reported on barley and wheat (Izadi et al. 2014) and lettuce (Tarakcioglu and Inal 2002).

Based on the results, salinity reduced $P_{\mathrm{N}}, g_{\mathrm{s}}$, and $E$ (Table 2). The effect of salinity on $P_{\mathrm{N}}$ could be through 
Table 2. Effect of $\mathrm{NaCl}$ salinity on leaf gas exchange of four lisianthus cultivars after 60 and 70 days from treatment. $\mathrm{C}_{1}-\mathrm{Blue}$ Picotee; $\mathrm{C}_{2}$ - Champagne; $\mathrm{C}_{3}$ - Lime Green; $\mathrm{C}_{4}-$ Pure White; $E$ - transpiration rate; $g_{s}$ - stomatal conductance; $P_{\mathrm{N}}-$ net photosynthetic rate. Mean values in each column followed by the same lowercase letters did not differ significantly at $P \leq 0.05$ according to LSD.

\begin{tabular}{lllllll}
\hline Treatment & \multicolumn{5}{l}{$P_{\mathrm{N}}\left[\mu \mathrm{mol} \mathrm{m} \mathrm{m}^{-2} \mathrm{~s}^{-1}\right]$} & \multicolumn{3}{l}{$E\left[\mathrm{mmol}\left(\mathrm{H}_{2} \mathrm{O}\right) \mathrm{m}^{-2} \mathrm{~s}^{-1}\right]$} & \multicolumn{2}{l}{$g_{\mathrm{s}}\left[\mathrm{mol}\left(\mathrm{H}_{2} \mathrm{O}\right) \mathrm{m}^{-2} \mathrm{~s}^{-1}\right]$} \\
& \multicolumn{6}{l}{ Time after treatment $[\mathrm{d}]$} \\
& 60 & 70 & 60 & 70 & 60 & 70 \\
\hline Cultivar & & & & & & \\
$\mathrm{C}_{1}$ & $2.6^{\mathrm{b}}$ & $2.5^{\mathrm{b}}$ & $2.9^{\mathrm{b}}$ & $3.6^{\mathrm{b}}$ & $0.128^{\mathrm{bc}}$ & $0.135^{\mathrm{b}}$ \\
$\mathrm{C}_{2}$ & $1.8^{\mathrm{c}}$ & $2.01^{\mathrm{c}}$ & $2.8^{\mathrm{b}}$ & $3.6^{\mathrm{b}}$ & $0.115^{\mathrm{c}}$ & $0.136^{\mathrm{b}}$ \\
$\mathrm{C}_{3}$ & $3.1^{\mathrm{a}}$ & $2.5^{\mathrm{ab}}$ & $3.2^{\mathrm{ab}}$ & $3.7^{\mathrm{b}}$ & $0.156^{\mathrm{a}}$ & $0.182^{\mathrm{a}}$ \\
$\mathrm{C}_{4}$ & $3.4^{\mathrm{a}}$ & $2.9^{\mathrm{a}}$ & $3.8^{\mathrm{a}}$ & $4.2^{\mathrm{a}}$ & $0.149^{\mathrm{ab}}$ & $0.139^{\mathrm{b}}$ \\
$\mathrm{LSD}$ & 0.414 & 0.46 & 0.533 & 0.35 & 0.021 & 0.021 \\
$\mathrm{NaCl}[\mathrm{mM}]$ & & & & & & \\
0 & $3.7^{\mathrm{a}}$ & $2.9^{\mathrm{a}}$ & $4.09^{\mathrm{a}}$ & $4.4^{\mathrm{ab}}$ & $0.184^{\mathrm{a}}$ & $0.167^{\mathrm{ab}}$ \\
10 & $3.8^{\mathrm{a}}$ & $2.7^{\mathrm{ab}}$ & $3.5^{\mathrm{ab}}$ & $4.01^{\mathrm{bc}}$ & $0.166^{\mathrm{ab}}$ & $0.188^{\mathrm{a}}$ \\
20 & $2.6^{\mathrm{bc}}$ & $3.2^{\mathrm{a}}$ & $3.3^{\mathrm{bc}}$ & $4.68^{\mathrm{a}}$ & $0.141^{\mathrm{bc}}$ & $0.178^{\mathrm{a}}$ \\
30 & $2.9^{\mathrm{b}}$ & $2.8^{\mathrm{a}}$ & $2.8^{\mathrm{cd}}$ & $3.82^{\mathrm{cd}}$ & $0.123^{\mathrm{cd}}$ & $0.147^{\mathrm{bc}}$ \\
40 & $2.1^{\mathrm{cd}}$ & $2.16^{\mathrm{bc}}$ & $2.9^{\mathrm{bcd}}$ & $3.42^{\mathrm{de}}$ & $0.132^{\mathrm{c}}$ & $0.12^{\mathrm{cd}}$ \\
50 & $2.0^{\mathrm{d}}$ & $1.9^{\mathrm{c}}$ & $3.09^{\mathrm{bcd}}$ & $3.3^{\mathrm{ef}}$ & $0.115^{\mathrm{cd}}$ & $0.117^{\mathrm{d}}$ \\
60 & $1.8^{\mathrm{d}}$ & $1.7^{\mathrm{c}}$ & $2.6^{\mathrm{d}}$ & $2.9^{\mathrm{f}}$ & $0.098^{\mathrm{d}}$ & $0.116^{\mathrm{d}}$ \\
LSD & 0.547 & 0.61 & 0.706 & 0.47 & 0.027 & 0.02 \\
$P_{\text {cultivar }}$ & $<0.0001$ & 0.0012 & 0.0022 & 0.0025 & $<0.0001$ & $<0.0001$ \\
$P_{\text {salinity }}$ & $<0.0001$ & $<0.0001$ & 0.0026 & $<0.0001$ & 0.001 & $<0.0001$ \\
$P_{\text {cultivar } \times \text { salinity }}$ & 0.0215 & 0.298 & 0.93 & 0.0127 & 0.208 & 0.064 \\
\hline
\end{tabular}

Table 3. Effect of $\mathrm{NaCl}$ salinity on some physiological and biochemical characteristics of four lisianthus cultivars. $\mathrm{C}_{1}-\mathrm{Blue}_{\mathrm{Picotee}}$ $\mathrm{C}_{2}$ - Champagne; $\mathrm{C}_{3}$ - Lime Green; $\mathrm{C}_{4}$ - Pure White ; Chl - chlorophyll; EL - electrolyte leakage; MDA - malondialdehyde; $\mathrm{RWC}$ relative water content. Mean values in each column followed by the same lowercase letters did not differ significantly at $P \leq 0.05$ according to LSD.

\begin{tabular}{lllllll}
\hline Treatment & El [\%] & $\begin{array}{l}\text { Chl } a \\
{\left[\mathrm{mg} \mathrm{g}^{-1}(\mathrm{FM})\right]}\end{array}$ & $\begin{array}{l}\text { Chl } b \\
{\left[\mathrm{mg} \mathrm{g}^{-1}(\mathrm{FM})\right]}\end{array}$ & $\begin{array}{l}\text { Chl total } \\
{\left[\mathrm{mg} \mathrm{g}^{-1}(\mathrm{FM})\right]}\end{array}$ & $\begin{array}{l}\text { MDA } \\
{\left[\mu \mathrm{mol} \mathrm{g}^{-1}(\mathrm{FM})\right]}\end{array}$ & RWC [\%] \\
\hline Cultivar & & & & & & \\
$\mathrm{C}_{1}$ & $32.2^{\mathrm{b}}$ & $16.7^{\mathrm{ab}}$ & $5.4^{\mathrm{b}}$ & $23.2^{\mathrm{b}}$ & $4.53^{\mathrm{a}}$ & $74.25^{\mathrm{bc}}$ \\
$\mathrm{C}_{2}$ & $38.1^{\mathrm{a}}$ & $16.5^{\mathrm{b}}$ & $5.3^{\mathrm{b}}$ & $21.8^{\mathrm{b}}$ & $4.69^{\mathrm{a}}$ & $71.09^{\mathrm{c}}$ \\
$\mathrm{C}_{3}$ & $26.4^{\mathrm{c}}$ & $19.4^{\mathrm{a}}$ & $7.7^{\mathrm{a}}$ & $27.2^{\mathrm{a}}$ & $2.9^{\mathrm{b}}$ & $77.39^{\mathrm{ab}}$ \\
$\mathrm{C}_{4}$ & $21.5^{\mathrm{d}}$ & $18.6^{\mathrm{ab}}$ & $7.6^{\mathrm{a}}$ & $25.2^{\mathrm{ab}}$ & $2.81^{\mathrm{b}}$ & $82.13^{\mathrm{a}}$ \\
$\mathrm{LSD}$ & 3.53 & 2.82 & 1.50 & 3.81 & 0.626 & 4.98 \\
$\mathrm{NaCl}[\mathrm{mM}]$ & & & & & \\
0 & $24.6^{\mathrm{c}}$ & $20.03^{\mathrm{a}}$ & $8.2^{\mathrm{a}}$ & $28.2^{\mathrm{a}}$ & $2.73^{\mathrm{e}}$ & $80.68^{\mathrm{ab}}$ \\
10 & $26.4^{\mathrm{bc}}$ & $17.8^{\mathrm{ab}}$ & $6.6^{\mathrm{abc}}$ & $24.4^{\mathrm{abc}}$ & $3.17^{\mathrm{de}}$ & $83.24^{\mathrm{a}}$ \\
20 & $25.8^{\mathrm{bc}}$ & $19.7^{\mathrm{a}}$ & $7.4^{\mathrm{ab}}$ & $27.1^{\mathrm{ab}}$ & $3.48^{\mathrm{cde}}$ & $74.48^{\mathrm{bcd}}$ \\
30 & $28.4^{\mathrm{bc}}$ & $15.38^{\mathrm{b}}$ & $5.1^{\mathrm{c}}$ & $20.5^{\mathrm{c}}$ & $4.31^{\mathrm{ab}}$ & $78.6^{\mathrm{abc}}$ \\
40 & $29.8^{\mathrm{b}}$ & $17.1^{\mathrm{ab}}$ & $5.9^{\mathrm{bc}}$ & $23.09^{\mathrm{bc}}$ & $4.05^{\mathrm{abc}}$ & $74.86^{\mathrm{bc}}$ \\
50 & $34.6^{\mathrm{a}}$ & $18.01^{\mathrm{ab}}$ & $6.08^{\mathrm{bc}}$ & $24.09^{\mathrm{abc}}$ & $3.59^{\mathrm{bcd}}$ & $73.61^{\mathrm{cd}}$ \\
60 & $37.1^{\mathrm{a}}$ & $16.8^{\mathrm{ab}}$ & $6.3^{\mathrm{abc}}$ & $23.2^{\mathrm{bc}}$ & $4.8^{\mathrm{a}}$ & $68.02^{\mathrm{d}}$ \\
LSD & 4.68 & 3.73 & 1.98 & 5.04 & 0.828 & 6.59 \\
$P_{\text {cultivar }}$ & $<0.0001$ & 0.185 & 0.010 & 0.040 & $<0.0001$ & 0.0004 \\
$P_{\text {salinity }}$ & $<0.0001$ & 0.152 & 0.087 & 0.068 & 0.0001 & 0.0006 \\
$P_{\text {cultivar } \times \text { salinity }}$ & 0.0001 & 0.720 & 0.830 & 0.734 & 0.165 & 0.154 \\
\hline
\end{tabular}

reduced $\mathrm{CO}_{2}$ partial pressure in the leaves due to stomatal closure (Meloni et al. 2003, DeRidder and Salvucci 2007, Maksimović et al. 2010) and/or nonstomatal factors, such as (1) a decline in photosynthetic pigments as showed by our results (Table 3 ) and previous reports (Tabatabaei and
Ehsanzadeh 2016), and (2) a disturbance in homeostasis of $\mathrm{Na}^{+}$and $\mathrm{Cl}^{-}$ions and essential mineral nutrients (DionisioSese and Tobita 2000, Gunes et al. 2007). Moreover, lower $E$ may be explained by a decrease in $g_{\mathrm{s}}$ in the presence of high $\mathrm{NaCl}$ concentrations (Jia et al. 2002, Maksimović et 
al. 2010). However, the response of cultivars to salinity in terms of leaf gas-exchange parameters was different. While the highest $P_{\mathrm{N}}$ and $E$ were found in $\mathrm{C}_{4}$, the largest $g_{\mathrm{s}}$ was found in $\mathrm{C}_{3}$. Further studies may be required to find an explanation for different cultivar responses in leaf gasexchange characteristics to salinity stress.

Cell membrane permeability has long been used as an effective selection criterion for salinity tolerance in plants (Farooq and Azam 2006). Peroxidation of membrane lipids (which is measured by EL and MDA content) is an indication of membrane damage and leakage under salt stress conditions (Katsuhara et al. 2005). EL and MDA content increased as salinity level increased in all cultivars (Table 3). However, $\mathrm{C}_{1}$ and $\mathrm{C}_{2}$ showed higher EL and MDA contents compared to $\mathrm{C}_{3}$ and $\mathrm{C}_{4}$, suggesting that, oxidative damage induced by salt was more pronounced in these cultivars compared to $\mathrm{C}_{3}$ and $\mathrm{C}_{4}$.

RWC decreased as salinity level increased (Table 3). The early response of seedlings to salinity is lowering leaf water potential and RWC. The decrease in RWC is a result of high salt concentration of the external solution, which caused osmotic stress and dehydration at cellular level

\section{References}

Akram M. S., Ashraf M., Akram N. A.: Effectiveness of potassium sulfate in mitigating salt-induced adverse effects on different physio-biochemical attributes in sunflower (Helianthus annuus L.). - Flora 204: 471-483, 2009.

Anonymous: Standard Methods for the Examination of Water and Wastewater, Vol. 2. Pp. 4-132. American Public Health Association, American Water Works Association, Water Pollution Control Federation, \& Water Environment Federation., Washington D.C. 1915.

Bongi G., Palliotti A.: Olive. - In: Shaffer B., Anderson P.C. (ed.): Handbook of Environmental Physiology of Fruit Crops. Temperate Crops, Vol. 1. Pp.165-187. CRC Press, Boca Raton 1994.

Cassaniti C., Leonardi C., Flowers T.J.: The effects of sodium chloride on ornamental shrubs. - Sci. Hortic.-Amsterdam 122. 586-593, 2009.

Chartzoulakis K.S.: Salinity and olive: growth, salt tolerance, photosynthesis and yield. - Agr. Water Manage. 78: 108-121, 2005.

Chartzoulakis K., Loupassaki M., Bertaki M. et al.: Effects of $\mathrm{NaCl}$ salinity on growth, ion content and $\mathrm{CO}_{2}$ assimilation rate of six olive cultivars. - Sci. Hortic.-Amsterdam 96: 235-247, 2002.

DeRidder B.P., Salvucci M.E.: Modulation of Rubisco activase gene expression during heat stress in cotton (Gossypium hirsutum L.) involves post-transcriptional mechanisms. - Plant Sci. 172: 246-254, 2007.

Dionisio-Sese M.L., Tobita S.: Effects of salinity on sodium content and photosynthetic responses of rice seedlings differing in salt tolerance. - J. Plant Physiol. 157: 54-58, 2000.

Essa T.: Effect of salinity stress on growth and nutrient composition of three soybean (Glycine $\max$ L. Merrill) cultivars. - J. Agron. Crop Sci. 188: 86-93, 2002.

Farooq S., Azam F.: The use of cell membrane stability (CMS) technique to screen for salt tolerant wheat varieties. - J. Plant
(Chartzoulakis 2005). Bongi and Palliotti (1994) reported that a reduction in RWC caused a reduction in $P_{\mathrm{N}}$. Cultivars which can limit the accumulation of harmful elements and maintain a positive water balance in their tissues are more tolerant to salt. Our data indicated that, $\mathrm{C}_{3}$ and $\mathrm{C}_{4}$ grown under salinity showed lower reduction in RWCs compared with those in $C_{1}$ and $C_{2}$ suggesting that $\mathrm{C}_{3}$ and $\mathrm{C}_{4}$ cultivars can tolerate greater concentrations of salts than $\mathrm{C}_{1}$ and $\mathrm{C}_{2}$.

Conclusions: In the present study, salt stress reduced growth, RWC, photosynthetic pigments, and gas-exchange characteristics, while it enhanced root FM, root/shoot length ratio, EL and MDA content in all cultivars. According the results presented here, significant differences in salt tolerance were observed between the lisianthus cultivars, implying that these differences could be considered when selecting salt tolerant and sensitive cultivars. $\mathrm{C}_{3}$ and $\mathrm{C}_{4}$ could be recommended as resistant cultivars due to higher growth, water balance, leaf gas exchange, ion compartmentalization, and lower lipid peroxidation in response to salinity compared to $C_{1}$ and $C_{2}$.

Physiol. 163: 629-637, 2006.

Flowers T., Yeo A.: Breeding for salinity resistance in crop plants: where next? - Funct. Plant Biol. 22: 875-884, 1995.

Gómez-Pérez L., Valdez-Aguilar L.A., Sandoval-Rangel A. et al.: Calcium ameliorates the tolerance of lisianthus [Eustoma grandiflorum (Raf.) Shinn.] to alkalinity in irrigation water. HortScience 49: 807-811, 2014.

Gunes A., Inal A., Alpaslan M. et al.: Salicylic acid induced changes on some physiological parameters symptomatic for oxidative stress and mineral nutrition in maize (Zea mays L.) grown under salinity. - J. Plant Physiol. 164: 728-736, 2007.

Hafsi C., Lakhdhar A., Rabhi M. et al.: Interactive effects of salinity and potassium availability on growth, water status, and ionic composition of Hordeum maritimum. - J. Plant Nutr. Soil Sc. 170: 469-473, 2007.

Izadi M. H., Rabbani J., Emam Y. et al.: Effects of salinity stress on physiological performance of various wheat and barley cultivars. - J. Plant Nutr. 37: 520-531, 2014.

Jia W., Wang Y., Zhang S. et al.: Salt stress induced ABA accumulation is more sensitively triggered in roots than in shoots. - J. Exp. Bot. 53: 2201-2206, 2002.

Katsuhara M., Otsuka T., Ezaki B.: Salt stress-induced lipid peroxidation is reduced by glutathione S-transferase, but this reduction of lipid peroxides is not enough for a recovery of root growth in Arabidopsis. - Plant Sci. 169: 369-373, 2005.

Lichtenthaler H.K.: Chlorophylls and carotenoids: pigments of photosynthetic biomembranes. - Methods Enzymol. 148: 350382, 1987.

Lutts S., Kinet J., Bouharmont J.: NaCl-induced senescence in leaves of rice (Oryza sativa L.) cultivars differing in salinity resistance. - Ann. Bot.-London 78: 389-398, 1996.

Maggio A., Raimondi G., Martino A. et al.: Salt stress response in tomato beyond the salinity tolerance threshold. - Environ. Exp. Bot. 59: 276-282, 2007.

Maksimović I., Putnik-Delić M., Gani I. et al.: Growth, ion 
composition, and stomatal conductance of peas exposed to salinity. - Open Life Sciences. 5: 682-691, 2010.

Mavrogianopoulos G., Savvas D., Vogli V.: Influence of NaClsalinity imposed on half of the root system of hydroponically grown tomato on growth, yield, and tissue mineral composition. - Environ. Exp. Bot. 77: 557-564, 2002.

Meloni D.A., Oliva M.A., Martinez C.A. et al.: Photosynthesis and activity of superoxide dismutase, peroxidase and glutathione reductase in cotton under salt stress. - Environ. Exp. Bot. 49: 69-76, 2003.

Mills H.A., Jones J.B., Wolf B.: Plant Analysis Handbook II: A Practical Sampling, Preparation, Analysis, and Interpretation Guide. Pp. 422. MicroMacro Publishing, Athens 1996.

Morales M., Sánchez-Blanco M., Olmos E. et al.: Changes in the growth, leaf water relations and cell ultrastructure in Argyranthemum coronopifolium plants under saline conditions. - J. Plant Physiol. 153: 174-180, 1998.

Munns R.: Genes and salt tolerance: bringing them together. New Phytol. 167: 645-663, 2005.

Navarro A., Bañón S., Conejero W. et al.: Ornamental characters, ion accumulation and water status in Arbutus unedo seedlings irrigated with saline water and subsequent relief and transplanting. - Environ. Exp. Bot. 62: 364-370, 2008.

Pattanagul W., Thitisaksakul M.: Effect of salinity stress on growth and carbohydrate metabolism in three rice (Oryza sativa L.) cultivars differing in salinity tolerance. - Indian J. Exp. Biol. 46: 736-742, 2008.

Pérez-Tornero O., Tallón C.I., Porras I. et al.: Physiological and growth changes in micropropagated Citrus macrophylla explants due to salinity. - J. Plant Physiol. 166: 1923-1933, 2009.

Poustini K., Siosemardeh A.: Ion distribution in wheat cultivars in response to salinity stress. - Field Crop. Res. 85: 125-133, 2004.

Rengasamy P.: World salinization with emphasis on Australia. J. Exp. Bot. 57: 1017-1023, 2006.

Ruiz-Carrasco K., Antognoni F., Coulibaly A.K. et al.: Variation in salinity tolerance of four lowland genotypes of quinoa (Chenopodium quinoa Willd.) as assessed by growth, physiological traits, and sodium transporter gene expression. Plant Physiol. Bioch. 49: 1333-1341, 2011.

Saab I.N., Sharp R.E., Pritchard J. et al.: Increased endogenous abscisic acid maintains primary root growth and inhibits shoot growth of maize seedlings at low water potentials. - Plant
Physiol. 93: 1329-1336, 1990.

Sairam R.K., Rao K.V., Srivastava G.: Differential response of wheat genotypes to long term salinity stress in relation to oxidative stress, antioxidant activity and osmolyte concentration. - Plant Sci. 163: 1037-1046, 2002.

Shahbaz M., Ashraf M., Akram N.A. et al.: Salt-induced modulation in growth, photosynthetic capacity, proline content and ion accumulation in sunflower (Helianthus annuus L.). Acta Physiol. Plant. 33: 1113-1122, 2011.

Sharma L., Kaushal M., Bali S. K. et al.: Evaluation of rough lemon (Citrus jambhiri Lush.) as rootstock for salinity tolerance at seedling stage under in vitro conditions. - Afr. J. Biotechnol. 12: 6267, 2013.

Shi G., Cai Q.: Cadmium tolerance and accumulation in eight potential energy crops. - Biotechnol. Adv. 27: 555-561, 2009. Shimizu-Yumoto H., Ichimura K.: Combination pulse treatment of 1-naphthaleneacetic acid and aminoethoxyvinylglycine greatly improves postharvest life in cut Eustoma flowers. Postharvest Biol. Tec. 56: 104-107, 2010.

Tabatabaei S., Ehsanzadeh P.: Photosynthetic pigments, ionic and antioxidative behaviour of hulled tetraploid wheat in response to NaCl. - Photosynthetica. 54: 340-350, 2016.

Tarakcioglu C., Inal A.: Changes induced by salinity, demarcating specific ion ratio $(\mathrm{Na} / \mathrm{Cl})$ and osmolality in ion and proline accumulation, nitrate reductase activity, and growth performance of lettuce. - J. Plant Nutr. 25: 27-41, 2002.

Tarchoune I., Degl'Innocenti E., Kaddour R. et al.: Effects of $\mathrm{NaCl}$ or $\mathrm{Na}_{2} \mathrm{SO}_{4}$ salinity on plant growth, ion content and photosynthetic activity in Ocimum basilicum L. - Acta Physiol. Plant. 34: 607-615, 2012.

Turhan A., SSeniz V.: Salt tolerance of some tomato genotypes grown in Turkey. - J. Food Agric. Environ. 8: 332-339, 2010.

Valdez-Aguilar L. A., Grieve C.M., Poss J.A.: Response of Lisianthus to irrigation with saline water: plant growth. J. Plant Nutr. 36: 1605-1614, 2013.

Valdez-Aguilar L.A., Grieve C.M., Poss J.A.: Response of Lisianthus to irrigation with saline water: ion relations. J. Plant Nutr. 37: 546-561, 2014.

Walsh L.M., Douglas L.A.: Instrumental Methods for Analysis of Soils and Plant Tissue. Pp. 500. Soil Science Society of America, Madison 1972

Wang F., Zeng B., Sun Z. et al.: Relationship between proline and $\mathrm{Hg}^{2+}$-induced oxidative stress in a tolerant rice mutant. Arch. Environ. Con. Tox. 56: 723-731, 2009. 